\title{
Towards a Comparative Understanding of Rulership: Discourses, Practices, Patterns
}

\author{
Jeroen Duindam
}

The preceding chapters have focused on connections between centres and peripheries, rulers and populations. Notwithstanding the routines of government-by-paper, particularly developed in China, these connections necessarily also took shape in two characteristic forms: agents representing the ruler and direct interactions between rulers and their populations.

High-profile trouble-shooters personally representing the ruler operated in distant territories or carried special responsibilities for solving crises; routine administrators administered core lands, where standard patterns of governance prevailed. Agents could rise through steady and competent loyal service or be catapulted into power because of their lineage and the ruler's favour. The career patterns systematically examined by Kent Guy for Qing China show an established practice of bureaucratic evaluation; in addition Guy underlines the impact of local connections and recommendations as well as the personal involvement of the ruler and his advisors. Metin Kunt's discussion of the Ottoman case suggests that the balance among these factors could shift dramatically, with central leadership's choices indirectly causing devolution and the rise of local elites. In Europe, a similar mixture of rulers' personal initiatives, administrative procedure, and localised responses determined the changing patterns of centre and periphery-only in the course of the seventeenth century, however, did the standards of administrative procedure in Europe approach those of Imperial China. Moreover, the persistence of nobilities in the upper layers of executive office in Europe and the marked presence of semi-hereditary high office in some countries set the European experience apart from most Asian examples. ${ }^{1}$

1 During the 2011 Leiden conference on 'Servants and Administrators: from the Court to the Provinces' Julian Swann (Birkbeck) presented a paper on the Condé princes as governors of Burgundy, Joseph Bergin (Manchester) gave a paper on French clergy at court and in the provinces. On French governors and Estates, see Julian Swann, Provincial power and absolute monarchy. The Estates General of Burgundy, 1661-179o (Cambridge, 2003); on the Condé, Katia Béguin, 'Louis XIV et l'aristocratie: coup de majesté ou retour à la tradition', Histoire, économie et société 19, no. 4 (2000), 497-512 and her Les princes de Condé. Rebelles, courtisans et mécènes dans la France du grand siècle (Paris, 1999). 
Dynastic power can be examined effectively only with combined political and cultural perspectives - it is difficult to draw a line between these overlapping domains. The cultural clichés of rule, didactically presented in discourses opposing good and bad examples of rulership or in moral codices outlining the ideal ruler, set standards for rulers and permeate the literary legacy of the court. This normative worldview also affected the representation of rulership to wider audiences, in interactive practices such as sacrifices, ceremonies, processions, and tours but also in buildings, printed media, or visual arts. The ideals of rulership, reflected in numerous tracts across the Eurasian continent, clearly show similarities as well as marked differences. There is some consensus on the key responsibility of rulership, protecting harmony and shielding the weak against the predations of the mighty, inherent in the mandate of heaven, in the Islamicate idea of sultanic power protecting the vulnerable against the wrongdoings of the powerful $(z u l m)$, or in the European notion of the prince as guardian of the bonum publicum and religious concord. This compelling idea, rarely a neat match with the actual behaviour of rulers, did underline the importance of access and petitioning or at least some form of an 'ombudsman'-system that allowed the populace to voice its grievances. ${ }^{2}$ This shared ideal structured as well as restricted the forms of princely representation. Chinese literati, Patricia Ebrey points out, were keen to remind the emperor of his heavy ritual and moral responsibilities, censuring overly spendthrift, martial, or peripatetic lifestyles. While similar attitudes can be found among religious advisors around kings and sultans, most 'princely mirrors' leave far more room for generous display as well as for military leadership. ${ }^{3}$ Rulers are universally

2 See e.g. Edward A. Kracke Jr., 'Early Visions of Justice for the Humble in East and West', Journal of the American Oriental Society 96, no. 4 (1976), 492-498; J.R. Perry, 'Justice for the Underprivileged: The Ombudsman Tradition of Iran', Journal of Near Eastern Studies 37, no. 3 (1978), 203-215; Linda T. Darling, 'Do Justice, Do Justice, For That is Paradise. Middle Eastern Advice for Indian Muslim Rulers', Comparative Studies of South Asia, Africa and the Middle East 22, no. 1-2 (2002), 3-19; Qiang Fang, 'Hot Potatoes: Chinese Complaint Systems from Early Times to the Late Qing (1898)', Journal of Asian Studies 68, no. 4 (2009), 1105-1135; Nimrod Hurvitz, 'The Contribution of Early Islamic Rulers to Adjudication and Legislation: the Case of the Mazalim Tribunals', in Jeroen Duindam, Jill Harries, Caroline Humfress, Nimrod Hurvitz, eds., Law and Empire: Ideas, Practices, Actors (Leiden, 2013), 135-156.

3 On Islamicate advice literature in general see Louise Marlow, 'Advice and advice literature', in Gudrun Krämer et al., ed., Encyclopaedia of Islam (Brill Online, 2012); Marlow, 'Kings, Prophets and the 'Ulamā' in Mediaeval Islamic Advice Literature', Studia Islamica 81 (1995), 101-120; also see the introduction to Sajida Alvi, Advice on the Art of Governance: An IndoIslamic Mirror for Princes (Mau'izahi Jahangiri) of Muhammad Baqir Najmi Sani Persian Text (Albany, 1989). 
advised to heed their councillors, particularly those offering candid criticism, yet the Chinese position on the whole seems to depict the ruler as a relatively passive figure, authorising government by others rather than actively governing himself. European and Islamicate West Asian rulers were expected to take a more active stance, and valour ranked high among princely virtues.

How do such cultural codes relate to practices? Ebrey shows that we should not take at face value the admonishments of gentlemen-scholars at court: their stylised complaints were not even necessarily intended to influence the emperor, who, moreover, could to some extent ignore them in practice. ${ }^{4}$ Nevertheless, the contrast with the world of splendour depictedor constructed - in the festival books critically examined by Helen WatanabeO'Kelly is remarkable. Indeed, European court life has often been depicted in terms of 'conspicuous consumption'. Imposing palaces and rich court celebrations created an image of courtly extravagance, broadcast by lavishly produced tomes, medals, paintings, and other media. The image was taken up eagerly by revolutionary propagandists and on the whole accepted at face value by later historians. Looking behind the scenes by examining court ordinances, we glimpse a different world where making ends meet was a permanent concern: ordinances reiterate rules designed to control costs and prevent waste or embezzlement. Great festivals and ceremonies overawed the beholder, suggesting magnificence and wealth-yet ceremonial agents were specialists in recycling materials and reducing costs. ${ }^{5}$ Neither their strenuous efforts nor the contestations frequently disturbing the show of splendour and hierarchy necessarily found their way into the festival descriptions that conveyed the image of an untroubled world of court entertainments to more distant audiences.

No historian will be surprised to hear that different sources create different perspectives; in a comparative study, however, this age-old wisdom gains unexpected significance. Literary traditions in Europe, China, and elsewhere have exerted a powerful influence on our understanding of courts and rulers in history. Sources circumventing, complementing, and correcting these normative and idealised court-based literary legacies are essential if we are to approach

4 See David Robinson, Martial Spectacles of the Ming Court (Cambridge Mass., 2013) reflecting many of the tensions discussed in Ebrey, but showing the continuity of hunting and other 'martial' practices under many Ming emperors.

5 See Jeroen Duindam, Vienna and Versailles. The Courts of Europe's Dynastic Rivals ca. 15501780 (Cambridge, 2003), outlining court routines; W.R. Newton, Derrière la façade. Vivre au château de Versailles au XVIII e siècle (Paris, 2008) details the less than magnificent living conditions in Versailles. 
more closely the actual lives of emperors, their agents, and the wider popular perceptions of those in power. The turn towards unpublished and hitherto frequently ignored sources has substantially changed the historiography of European rulers and their courts. Michael Chang shows how the juxtaposition of several court-based and local sources on the Kangxi emperor's 1684 visit to Suzhou raises all sorts of intriguing questions. We can expect a shift in Late Imperial Chinese history when a greater variety of sources becomes available to qualify and sometimes question the immutable world of the Veritable Records.

The interaction between the dynastic ruler and the population at large assumed many forms, the extremes ranging from folksy figures mingling freely with the commonest among their subjects to rulers living in almost total seclusion in the palace. Finding a position along the continuum between accessibility and withdrawal was relevant for all courts as well as for all individual rulers. This universal aspect of court life was dictated by various influences and requirements, relating to the cultural codes of rulership, the ruler's personality, concerns of security, and strategies of representation. How much of the population in Imperial China, the Ottoman empire, or-say-early modern France ever actually set eyes on the ruler with his retinue? Did the dynastic centre play a conspicuous role in the lives of ordinary subjects? Popular tales and proverbs powerfully suggest that kings and emperors were present in the mental map of their subjects, but outside of the capital and its immediate surroundings their imagined presence can only rarely have been reinforced by actual meetings. Such events, as the papers by Michael Chang, Margit Thøfner, and Neil Murphy remind us, could have a significant and lasting impact. At the same time the visits, processions, and entries were always to some extent improvised, reflecting the preparations, expectations, and intentions of various parties. In the European context we know that ceremony, often thought to follow a wholly rigid choreography, in practice left much to the initiative of the participants. ${ }^{6}$ Thøfner gives some remarkable examples of ceremonial improvisation by the main participants in Joyous Entries. Her careful examination of the written and visual representation of Joyous Entries warns against misreading such events as an uncomplicated show of sovereign power. Murphy highlights how the format of the entries embodied and influenced the connections between cities and the prince: entries '... were not just representations of the theoretical workings of the state; they were the very occasions during

6 See chapter 6, 'Ceremony and order at court: an unending pursuit', Duindam, Vienna and Versailles, 181-219. 
which the political bond between the king and his urban subjects was brought into being. ${ }^{7}$ Christian Büschges, in another context, makes clear that ceremonial and political action cannot be separated: ceremony not only made visible ranks and relationships, it had the potential to change them. Rangs et séances were more than a sideshow.

These authors make explicit an aspect equally relevant for the contributions on agents: power is a relationship rather than the attribute of a single person or party. Local interests, regional patronage networks, the agents shuttling back and forth between centre and peripheries, different competing groups at the centre, and finally the ruler: at each level the balances among various groups determined outcomes. A forceful figure-first emperor, talented monarchcould operate so effectively that dissent at the centre remained muffled, securing the smooth operation of the chain of command of officeholders and a relatively unchallenged authority in the localities. Yet the resentment generated by periods of concentrated - and periodically violent - authority made likely a backlash within the ruler's lifecycle, when his grip weakened in old age. Otherwise succession, always a critical point for dynastic power, would bring change: either wreaking havoc through the contestations among rivals or simply by introducing mediocre leadership. A sequence of highly talented dynastic rulers such as that of the Kangxi, Yongzheng, and Qianlong emperors remains a rare exception.

Similar patterns become clear in Yincong Dai's analysis of Nayancheng's career and the responses of the Jiaqing emperor. Here, too, we see the impact of a tradition, the role of divided central elites, the performance of an individual agent, and finally the shifting attitude of the emperor himself gradually moving towards a different political setup. Change did not start with unambiguously clear policy choices but emerged as the consequence of a long and muddled process, an accumulation of ad hoc responses. However, in the end a new pattern of ruling without a favourite grand councillor became accepted practice, relocating power to a somewhat wider circle of grandees and ministers. Metin Kunt's paper on the Ottoman provincial governors likewise questions the notion of the ruling elite's predetermined choices. Some of the fundamental changes he describes (the change in the role of princes; the rise of local agency) reflect a series of impromptu adaptations as well as the interference of contesting groups at many levels. Apparently high policy

7 See Neil Murphy in this volume, and his 'Royal Grace, Royal Punishment: Ceremonial Entries and the Pardoning of Criminals in France, c. 1440-1560', in Duindam et al., eds., Law and Empire: Ideas, Practices, Actors, 293-311. 
choices, seen from the ground, more often are unintended consequences than premeditated outcomes.

For this volume, we invited the contributors to consider our general themes in the context of their specific cases: the implicit confrontation of these different but interconnecting examples, we hoped, would itself trigger comparative speculation even if we did not choose to provide a ready comparative framework. Yet does this volume as a whole contribute to a comparative understanding of rulership, political agency, and ritual interaction? From the preceding tour d'horizon some closely connected suggestions about comparison can be inferred.

First of all, the normative worlds of dynastic power need to be put into a comparative perspective before we can effectively evaluate the structures and practices of power. The discourses generated by court life across the globe show sufficient interconnection to be measured against one another. Understanding the discrepancies in such views on rulership is an important goal, but it also represents a necessary condition for further comparative study. The comparative knowledge of the topoi of rulership makes it easier to put sources into context and to differentiate between standard discourses and individual variations. Moreover, such knowledge will be of prime importance in locating and using sources supplementing and correcting the familiar images of dynastic power and ceremonial order: only then can we move from discourses to practices.

Secondly, dynastic power can best be approached through a combination of cultural and political perspectives. In other words: we should consider the political relevance of ritual and ceremonial occasions as well as the cultural conventions involved in political interaction. Moreover, many occasions cannot be compartmentalised in either of these categories. The ritual dimension of dynastic rule was of foremost importance. Without a doubt, rulers could be astute politicians using magnificence and ritual to demonstrate their power; yet they at least at times took very seriously the burden they carried. The dissonance between the ruler's celestial mandate and his own standards of behaviour as well as that between the high-minded ideals and political trafficking of the court elites created tensions that, to some extent, are an inevitable component of any political system.

Thirdly, there is little reason to restrict political agency to the ruler, who nominally stood at the heart of the political setup. The elevated position of the dynastic ruler more often than not circumscribed the freedom of manoeuvre 
of the incumbent; at the same time, it empowered those around him-or occasionally her. The competition among different groups around the ruler, often shaped in 'inner' or domestic and 'outer' or administrative domains, with an innermost core of spouses and concubines, resonates in the history of the court. However, agency did not stop at the palace gates: corporations and individuals, in the capital, in the provinces, and on the frontier defined their own aims and strategies. Only a comparison that takes into account major differences in cultural representation and the problems of the dominant sources can effectively test the assumption that countervailing forces or corps intermédiaires were much stronger and more vocal in the European than in the Ottoman or Chinese settings. This volume strongly suggests that we cannot take this classic position for granted.

Dynastic power, theoretically in the hand of a single figure, in practice emerged as an ongoing tussle among many groups and layers. This contestation could be open and violent but more often was muted, with the contenders packaging their attacks in cultural clichés and the polite formulae of hierarchical society. Moreover, ritualised encounters were as formative for the political constellation as administrative procedure.

The themes discussed here invite more systematic follow-up. The recruitment, training, and career patterns of agents demand a comparative examination, which probably can be done only on the basis of painstaking long-term research such as the work of Kent Guy on the Qing governors, research that remains undone for many states and empires. ${ }^{8}$ Likewise a comparative analysis of control mechanisms used by rulers to secure the loyalty of agents over time, from Carolingian missi dominici and Chinese censors to variants of the job carrousel and evaluation, ranking or remuneration systems, needs more preliminary work. The global catalogue of rulers' virtues calls for comparison, made somewhat easier by the availability of numerous translations of Arabic and Chinese texts. ${ }^{9}$ Rules defining and regulating access are present in most court archives, and the same holds true for arrangements for outward movement and travel. They invite further comparison, for which this volume provides a modest initial effort. Visits and entries, confirming, re-enacting and redefining the ties with cities in the realm, form a focus of this volume that

8 See R. Kent Guy, Qing Governors and Their Provinces: The Evolution of Territorial Administration in China, 1644-1796 (Seattle, 2010); Metin Kunt, The Sultan's Servants: The Transformation of Ottoman Provincial Government, 1550-1650 (New York, 1983), and the works cited in note 1 above. For most states and empires, we lack comprehensive prosopographical works.

9 See the works cited in note 3, and e.g. Theodore Wm. De Bary, ed., Huang Zongxi, Waiting for the dawn: a plan for the prince Huang Tsung-his's Ming-i-tai-fang-lu (New York, 1993). 
can easily be extended to other examples. The multiplication of cases can assist the formulation of more probing comparative questions. ${ }^{10}$ By juxtaposing papers on closely related themes, each based on direct knowledge of the relevant sources, on agents of dynastic power as well as on the ritual connections between centre and periphery, we hope to have given a foretaste of and a modest starting point for comparison that combines contextual regionalised knowledge with a global horizon.

10 See e.g. Tülay Artan on procession, 'Royal Weddings and the Grand Vezirate: Institutional and Symbolic Change in the Early Eighteenth Century, in Jeroen Duindam, Metin Kunt and Tulay Artan, ed., Royal courts in dynastic states and empires: a global perspective (Leiden and Boston, 2011), 339-399; Jenny Rahel Oesterle, Kalif und König. Herrschaftsrepräsentation der Fatimiden, Ottonen und frühen Salier an religiösen Hochfesten (Darmstadt, 2009) Symbolische Kommunikation in der Vormoderne. Studien zur Geschichte, Literatur und Kunst, Gerd Althof, Barbara Stollberg-Rilinger, Horst Wenzel, ed. 